\title{
TRÊS NARRATIVAS SOBRE A PRESENÇA DO PEQUENO LIVRO \\ VERMELHO DE MAO TSÉ TUNG \\ NA RESISTÊNCIA À DITADURA MILITAR, NO RECIFE
}

\author{
Elaine C. Gomes da Cunha ${ }^{1}$ \\ Juliana Carla Beserra da Silva ${ }^{2}$ \\ Raquel Torres da C. e Silva ${ }^{3}$
}

\begin{abstract}
Resumo:
O Pequeno Livro Vermelho de Mao Tsé Tung é um dos marcos na construção histórica da República Popular que mais influenciou as gerações de jovens revolucionários, dentro e fora da China. Apesar disso, ainda são poucos os estudos que se debruçam sobre a importância desse compêndio de citações do "Camarada Mao" para os movimentos socialistas além das fronteiras chinesas, sobretudo quando se considera a produção acadêmica brasileira. O intuito do presente artigo é - através da história oral e da análise de bibliografia pertinente - apresentar narrativas e vivências acerca da presença dessa publicação no cotidiano de muitos dos que, naquele momento, lutavam contra o regime ditatorial no Brasil, defendendo o caminho do comunismo, ou reivindicavam uma alternativa econômica e política diferente.
\end{abstract}

Palavras-chave: Livro Vermelho de Mao, Ditadura Militar em Recife, Revolução Cultural Chinesa.

\begin{abstract}
Mao Tse Tung's Little Red Book is one of the milestones in the historical construction of the People's Republic that most influenced as generations of young revolutionaries inside and outside China. Despite that, there are few studies about the importance of this compendium of citations of the "Chairman Mao" to the socialist movements beyond Chinese borders, especially when we consider the Brazilian academic production. The aim of this article is - through oral history and analysis of pertinent bibliography - to present narratives and experiences about the presence of this publication on the everyday life of many of those who, at that time, were fighting against the dictatorial regime in Brazil, defending the path of communism, or claiming a different economic and political alternative.
\end{abstract}

Keywords: Mao’s Little Red Book, Military dictatorship in Recife, Chinese Cultural Revolution.

O Pequeno Livro Vermelho foi um dos principais instrumentos de doutrinação e difusão do maoísmo, sobretudo para além das fronteiras chinesas. Sua popularização e influência no Ocidente - o qual fervilhava de manifestações populares e de transformações sócio-políticas no final dos anos de 1960 - é um tema ainda muito pouco explorado, sobretudo quando se considera o contexto brasileiro. Com o objetivo de ampliar a percepção histórica sobre esse contexto, as autoras do presente texto tiveram a oportunidade, em 2005, de entrevistar três sujeitos cuja história de luta na militância política contra a Ditadura Militar no Brasil foi intensamente atravessada pelas palavras contidas no Pequeno Livro Vermelho de Mao. Foram eles: Tereza Costa Rêgo, renomada pintora brasileira; Lilia Gondim, economista e ex-presa política; e Luciano

\footnotetext{
${ }^{1}$ Mestre em História pela Universidade Federal Rural de Pernambuco. Atualmente é doutoranda em História da Educação pela Universidade de Coimbra. Contato: Rua Deputado Cunha Rabelo, Várzea, Recife-PE, Brasil. Email: angelusnovus888@gmail.com.

${ }^{2}$ Mestranda em História pela Universidade Federal de Pernambuco. Contato: Contato: Rua Pereira da Costa, n. 41, Pina - Recife-PE, Brasil. E-mail: julianabeserra@ yahoo.com.br.

3 Graduada em História (Bacharelado e Licenciatura) pela Universidade Federal de Pernambuco, Atualmente é graduanda em psicologia pela mesma universidade. E-mail: quelcostaesilva@gmail.com.
} 
Siqueira, à época da entrevista vice-prefeito do Recife na gestão de João Paulo e atual vice-prefeito na gestão de Geraldo Júlio. Seus relatos estão reproduzidos ao final do artigo, uma vez que o objetivo maior é dar destaque às suas rememorações.

É importante destacar que, na perspectiva da História Oral, as fontes orais - que têm a memória como arcabouço - não são percebidas como a própria História, e sim como testemunhos que dão acesso a "histórias dentro da história", ampliação das possibilidades de interpretação do passado. Da mesma forma, não se entende a memória como uma representação estática de um passado objetivamente registrado, mas sim como um campo dinâmico, constantemente ressignificado no presente durante o próprio processo de rememoração e de elaboração de relatos. Nesse sentido, o sujeito produtor da narrativa é também um sujeito produtor de significados: ${ }^{5}$

A narrativa gravada em uma entrevista não constitui-se na memória propriamente, pois esta é inacessível; configura-se como a construção de uma determinada vivência a partir da memória. Durante o processo de rememoração o depoente estabelece relações entre suas próprias experiências que o permite reconstruir seu passado segundo uma determinada estrutura, consciente ou não. É o tecer de uma teia na qual suas vivências vão sendo reorganizadas, proporcionando a cada ato de rememorar uma nova construção através de um determinado encadeamento de ideias, estruturado pela valoração simbólica de sua própria personalidade e viabilizado mediante a construção do relato. ${ }^{6}$

É a partir desses referenciais teóricos que se pode entender, portanto, a entrevista enquanto uma fonte oral que requer rigor, responsabilidade e cuidado metodológico. Antes, entretanto, de aprofundar essas questões a partir das narrativas dos entrevistados sobre suas vivências com o livro de Mao durante a luta política no Brasil ditatorial, consideramos pertinente realizar uma contextualização acerca do Livro Vermelho e de seu papel na Revolução Comunista Chinesa.

\footnotetext{
${ }^{4}$ ALBERTI, Verena. "Histórias dentro da História". In: PINSKY, Carla Bassanezi (Org.). Fontes históricas. São Paulo: Contexto, 2008.

${ }^{5}$ RAPCHAN, Eliane Sebeika. "O uso da narrativa nas Ciências Sociais: algumas notas e reflexões acerca de suas possibilidades". In: MONTENEGRO, Antônio Torres; FERNANDES, Tania Maria (Orgs.). História Oral: um espaço plural. Recife: Universitária, 2001.

${ }^{6}$ FERNANDES, Tania Maria. "Edição de entrevista: de linguagem falada à escrita". In: História Oral: um espaço plural. Op. Cit. p. 92.
} 


\section{O Pequeno Livro Vermelho e a Revolução Cultural Chinesa}

Após a Revolução Chinesa, especificamente após a vitória dos comunistas chineses sobre os nacionalistas do Kuomintang, ${ }^{7}$ a cúpula do Partido Comunista Chinês (PCC) iniciou um conjunto de reformas que visava à implantação não apenas da ideologia comunista, mas do modelo econômico focado no proletariado. Porém, para que tal modelo fosse executado, a nação asiática, que até então era predominantemente agrícola, precisava instalar zonas industriais, assim como lidar com a fome e miséria em todo continente. Através de acordos com a então União das Repúblicas Socialistas Soviéticas (URSS), confluíram à China técnicos, burocratas e intelectuais russos de modo a trocarem informações sobre a construção de parques industriais e de formação de um proletariado ancorado em ideais socialistas.

Entretanto, a partir do final da década dos anos de 1950 do século passado, e por discordância dos caminhos adotados pelo Partido Comunista Soviético, Mao Tsé Tung passou a elaborar reformas que consolidassem o seu projeto comunista para a China. Além disto, o país sofreu com grandes catástrofes naturais que impactaram na economia e na vida de milhares de chineses, pressionando a elaboração e reformulação de medidas que possibilitassem a adesão ideológica dos trabalhadores ao ideal maoísta, especialmente dos jovens, para que eles assegurassem o futuro da revolução.

Assim, iniciou-se, em 1962, o Movimento de Educação Socialista o qual visava à consolidação dos aliados de Mao, e dele próprio, frente ao crescente prestígio e poder de grupos burocráticos no seio do partido comunista. Esta "rivalidade" interna, deflagrou, na segunda metade dos anos 60, a Grande Revolução Cultural Proletária.

Ressalta-se a participação ativa de Lin Piao, ${ }^{8}$ em todas as reformas propostas, sendo ele o responsável por ter apresentado à Comissão de Assuntos Militares uma série trechos retirados dos textos de Mao Tsé Tung que deveriam fazer parte das mochilas entregues aos jovens soldados chineses. Esta série, portanto, foi a base do livro lançado em 1 de agosto de 1965 intitulado Citações do Presidente Mao Tsé Tung que, por ter

7 Também conhecido como Partido Nacionalista Chinês. Governou a China Continental até 1949 e identificado como aliado dos interesses da elite chinesa.

${ }^{8}$ Participou ativamente na luta contra os japoneses durante a invasão destes à China, na Segunda Guerra Mundial. Foi Ministro da Defesa no período do governo de Mao e nomeado, no IX Congresso do Partido Comunista Chinês, como seu sucessor oficial. Entretanto, foi desacreditado e morreu em uma queda de avião durante a fuga. 
sido encadernado com capa vermelha, terminou sendo conhecido no Ocidente como o Pequeno Livro Vermelho.

Apesar de o livro ter como público alvo os jovens militares, ao longo do final dos anos 60, as citações de Mao circularam entre camponeses e operários:

À medida que o ritmo da Revolução Cultural se acelerava, excertos das Citações começaram a aparecer por toda a parte: no alto da pagina de todos os periódicos, no começo e no fim, senão no meio, de qualquer espetáculo cultural, em grandes caracteres colados às paredes dos edifícios, e em gigantescas tabuletas ao longo das estradas. ${ }^{9}$

Logo, ler e compreender o Pequeno Livro Vermelho era fazer parte tanto da Revolução Cultural quanto da própria evolução e manutenção da República Popular da China. Sua idéia essencial era manter o fervor revolucionário e um estado constante de luta e superação, ${ }^{10}$ sem os quais, segundo Mao, a revolução comunista estaria fadada ao fracasso: "Os manuais e o Livrinho Vermelho de Mao foram, durante muitos anos, nossa única fonte de conhecimento intelectual. Todos os outros livros eram proibidos". ${ }^{11}$

Qualquer questionamento neste sentido era punido ou com humilhações públicas ou mesmo com a morte, como descreve o autor anônimo abaixo sobre a Revolução Cultural e o papel do Livro Vermelho nela:

Época vergonhosa em que matilhas de imberbes, fanatizados pelas leituras do Livro Vermelho do Camarada Mao, - citações selecionadas pelo extremista Lin Piao -, tomaram de assalto as ruas, ocupando escolas, fábricas e repartições por todo o país, dando caça a quem consideravam contra-revolucionários. Quase toda a milenar cultura chinesa esteve ameaçada por hordas dos ultra-radicais (sic) insuflados pela Madame Mao [Chiang Ching], que não se detinham nem frente aos veneráveis tratados de Confúcio, de Mencio, ou de Lao Tse. (...) Arrastados pelas ruas - vestidos com patéticos sambenitos (vestimenta similar a uma túnica), com cartazes infamantes pendurados no peito, parecendo os sacrificados dos tempos da Santa Inquisição, as vítimas dos Guardas Vermelhos foram socadas e chutadas pelas turbas vociferantes, furiosas. Milhares foram linchados, em Xangai afogaram-nos em massa. Nem mesmo alguns membros alta hierarquia do partido comunista, os Zou Zi Pai, os dúbios, foram poupados. Como deu-se com Li Chao-Chi e Deng Xiaoping, que além de exonerado e desterrado, teve um filho seu aleijado quando a malta invadiu-lhe o apartamento. Qualquer

9 WITKE, Roxane. A Madame Mao. Rio de Janeiro: Nova Fronteira, 1977, p. 310.

${ }^{10}$ Isso porque os mais jovens representavam uma geração que não participou do processo revolucionário, ou seja, eles almejavam o engajamento, mas a revolução já havia sido feita.

${ }^{11}$ SIIJIE, Dai. Balzac e a Costureirinha Chinesa. Rio de Janeiro: Objetiva, 2001, p 9. 
coisa que parecia diferente, melhor, com mais qualidade, aos olhos daqueles igualitários loucos, atraia-lhes um ódio cego. ${ }^{12}$

O livro que estes dúbios, na perspectiva deste autor, carregavam nos bolsos ou como diversas gravuras indicam, balançavam no ar, é dividido em trinta e três capítulos que enfocam desde temas ligados diretamente à compreensão sobre o partido comunista, como o próprio significado do partido, ao valor do estudo e às mulheres. As citações foram retiradas de artigos elaborados por Mao Tsé Tung entre os anos de 1926 a $1964^{13}$ e não seguem necessariamente uma ordem cronológica, mas uma ordem temática. Em outras palavras, o elo comum entre as citações de determinado capítulo é o assunto abordado.

Essa organização do livro propiciou o denominado maoísmo que, "corporificado no Livro Vermelho", ${ }^{14}$ ultrapassou os limites do território chinês e alcançou o mundo através de inúmeras traduções e impressões. ${ }^{15}$ Mesmo após a abertura da China ao mercado, o que o Partido denomina de economia mista, ainda está presente na atualidade.

Entretanto, a leitura ou importância do Pequeno Livro Vermelho não foi entendida de forma positiva por todos ao redor do mundo, especificamente para homens e mulheres que pertenciam a setores religiosos, principalmente cristãos.

$\mathrm{Na}$ época na qual o Pequeno Livro Vermelho alcançou maior divulgação, final do decênio de 1960, grupos de orientação religiosa, como o Movimento dos Focolares, concebido por Chiara Lubich, a obra era vista de forma temerosa e necessitava ser combatida mesmo que de maneira sutil:

Chiara entregou aos jovens do Movimento um pequeno livro amarelo, com as etapas da revolução codificada do Evangelho.

12 Disponível em: < http://educaterra.terra.com.br/voltaire/atualidade/2002/11/19/000.htm > Acessado em $05 / 02 / 18$.

${ }^{13}$ Dentre estes artigos: Análise das classes da sociedade chinesa, Março de 1926; Relatório sobre uma investigação feita em Hunan a propósito do movimento camponês, Março de 1927; Sobre a eliminação das concepções errôneas no seio do Partido, Dezembro de 1929; Sobre a ditadura democrática popular, 30 de Julho de 1949; Sobre a questão da cooperativização agrícola, 31 de Julho de 1955; Conversa com os estudantes e estagiários chineses em Mosocovo, 17 de Novembro de 1957; Declaração em apoio à justa luta patriótica do povo panamense contra o imperialismo norte-americano, 12 de Janeiro de 1964.

14 O Livro Vermelho: citações do comandante Mao Tse-tung. São Paulo, Martin Claret, 2004. p 16.

15 Ainda hoje é considerado um dos livros mais lidos na História. Matéria disponível em: < https://www.terra.com.br/noticias/mundo/asia/meio-seculo-depois-livro-vermelho-de-mao-pode-ter-parte2-com-xi-jinping,161e67b159be154fb02367826df7a9b34ldw7n76.html > Acessado em 05/02/18. 
Naqueles mesmos anos, em Pequim, os jovens empunhavam o 'pequeno livro vermelho' de Mao. ${ }^{16}$

Além deste "pequeno livro amarelo", Lubich incentivou, nos anos seguintes, a fundação de centros voltados para a formação espiritual e social de jovens tanto na Europa quanto no continente africano denominados de "Geração Nova" através da releitura dos Evangelhos Cristãos.

Fora das fronteiras chinesas, a Grande Revolução Cultural Proletária e o Pequeno Livro Vermelho se disseminaram de tal forma até que houve o que se denominou de uma "moda maoísta", correspondente ao período de maior divulgação e utilização da obra no Ocidente. As notícias sobre a revolução enfatizavam os seus êxitos e encantavam os militantes comunistas ao redor do mundo. No Brasil, como será discutido em seguida, as citações do presidente chinês acompanharam muitas manifestações e conduziram muitos comportamentos de jovens revolucionários que se opunham à Ditadura Militar. É necessário, no entanto, entender o que representou a década de 1960 dentro de todo esse contexto, na política, na cultura, na sociedade.

\section{O mundo na década de 60}

Período de grandes contradições no panorama internacional, a década de 1960 conheceu o incrível avanço tecnológico e as manifestações da contracultura. A sociedade industrial avançava rompendo princípios, modificando as relações e as condições de vida; os meios de comunicação quebravam os valores regionais e introduziam uma cultura uniforme sem fronteiras. Em face de valores como o amor, a liberdade, a justiça e a fraternidade, surgia uma nova realidade - o consumo estabelecendo seus próprios valores: a eficácia, o sucesso, a competição.

A década de 40 havia assistido à expansão do socialismo, principalmente pelo Leste Europeu; a década de 50 foi palco de inúmeros atritos no mundo soviético, como o acirramento das tensões entre China e URSS. Nos anos 60, uma série de fatores

16 Chiara Lubich e a sua obra pelos direitos dos indivíduos e dos povos (notas biográficas). Disponível em: www.focolare.org/br/default.htm. Acessado em: 05/02/18. 
contribuiu para aumentar e agravar ainda mais as contradições dos anos anteriores. $\mathrm{Na}$ América Latina, por exemplo, seguiram-se vários golpes que instalaram ditaduras militares, como a do Brasil, a do Panamá, a do Peru. E em 1966, teve início a Revolução Cultural na China, que atingiu seu auge em 68. Aliás, o ano de 68 talvez tenha sido o mais representativo desse período. De acordo com Hobsbawm, em um artigo intitulado 68: "Quase se tem a impressão de que 68 pode ter sido planejado para servir como uma espécie de ponto de referência histórico. Nenhum daqueles de nós que vivemos o ano de 1968 vai esquece-lo, nunca". ${ }^{17}$

O sistema capitalista mundial, debilitado pela Guerra do Vietnã (1955-1975) que nesse ano mudou completamente o seu rumo a partir da ofensiva norte-vietnamita do Têt - pelas disputas interimperialistas, pela crescente inflação norte-americana e pelas frequentes manifestações de insatisfação, teve que enfrentar uma juventude irrequieta e contestatória, além de uma classe operária cada vez mais disposta à luta.

Além disso, o ressentimento antissoviético cresceu, e, na Europa Ocidental, outros partidos comunistas buscavam construir uma doutrina que fosse uma terceira via entre a socialdemocracia e o socialismo do bloco soviético. As reformas da "Primavera de Praga" (1968), que almejavam a atingir a um "socialismo humanizado", assustaram o governo da União Soviética, que invadiu a Tcheco-Eslováquia alegando que esta caminhava para o retorno ao capitalismo.

Dessa forma, grandes mobilizações, especialmente da juventude, desencadearam-se na França, Alemanha, Japão, Estados Unidos, México, Brasil. Aliás, esse foi um ano de forte presença dos jovens em praticamente todos os movimentos. Afinal, em apenas quarenta anos, o número dos jovens até 24 anos duplicaria, provocando, em 68, um crescimento vertiginoso do número de jovens.

Em maio de 68, a França assistiu ao que seria não apenas a maior mobilização estudantil de sua história, mas possivelmente sua maior greve geral. A juventude, que sentia os bloqueios políticos e institucionais do governo de Charles de Gaulle e recebia forte influência das lutas do terceiro mundo e do pensamento maoísta, explodiu como uma panela de pressão. A Iugoslávia, quase imediatamente após os "acontecimentos de maio", presenciou a eclosão de enormes manifestações estudantis. Na Cidade do

\footnotetext{
${ }^{17}$ HOBSBAWM, Eric. 68. Disponível em http://members.tripod.com/ Picheli/Hobsbawm.htm. Acesso em $25 / 03 / 18$
} 
México, o período de agitações estudantis atingiu seu ponto culminante num comício público feito antes dos Jogos Olímpicos, que resultou num grande massacre de estudantes. Na Alemanha Ocidental, a tentativa de assassinato de um líder estudantil desencadeou uma fase de agitação estudantil no país.

A constatação do fracasso da civilização criada pelas gerações anteriores - de guerras, injustiças sociais, violência, opressão - explodiu na consciência dos jovens dos anos 60, que passaram a negar todas as manifestações visíveis dessa civilização. Esses jovens criticavam a sociedade, reivindicavam liberdade política e contestavam a civilização de consumo que aliena o homem. Nesse período de questionamento global de todos os valores culturais e espirituais do ocidente, "a arma natural da revolta de 1968 não era o fuzil, ou a resolução política, mas o muro pichado, o cartaz improvisado e o microfone". ${ }^{18}$

No Brasil, além da efervescência cultural que fez florescer movimentos como o Cinema Novo, o teatro de Arena e o Tropicalismo, houve o recrudescimento do regime militar, que culminou com o AI-5. O assassinato do estudante secundarista Edson Luís de Lima pela Polícia Militar, no restaurante Calabouço, deu início a uma onda de manifestações e protestos que marcou o ano de 68. Ao mesmo tempo, proliferavam organizações revolucionárias como a Aliança Nacional Libertadora (ANL) e a Vanguarda Popular Revolucionária (VPR). O próprio presidente Costa e Silva, após a "Passeata dos Cem Mil", em que estudantes, artistas e intelectuais desfilaram aos gritos de "Abaixo a ditadura", exclamou: "Não permitirei que o Rio se transforme numa nova Paris!", ${ }^{19}$ em clara referência aos "acontecimentos de Maio" na França.

Toda essa movimentação foi acompanhada pelo aumento da atenção dada às obras de Mao, cuja popularização foi impulsionada pela divulgação de notícias exaltando a Revolução Cultural, o que estimulou e alimentou as esperanças de militantes comunistas em diversos países. Dessa forma, dentro desse caldeirão, as citações do presidente chinês se fizeram presentes na luta contra a Ditadura Militar no Brasil, conforme testemunham as três narrativas de jovens revolucionários aqui compiladas.

\footnotetext{
${ }^{18}$ Hobsbawm. Eric.68. Op. Cit.

${ }^{19}$ Citação retirada de PAES, Maria Helena Simões. A década de 60: Rebeldia, contestação e repressão política. $3^{a}$ ed. São Paulo: Ed. Ática, 1995 (Série Princípios). Pág. 68
} 


\section{O Pequeno Livro Vermelho no Brasil}

Aos entrevistados foi pedido que contassem um pouco de sua trajetória enquanto militantes e, dentro desse contexto, como teria se dado o contato com o Livro Vermelho, o que ele representava, como ele era utilizado e o que ele significou. $O$ enfoque nessas questões reflete a nossa escolha metodológica pelo tipo de entrevista denominada entrevista temática, adequada justamente

(...) para o caso de temas que têm estatuto relativamente definido na trajetória de vida dos depoentes, como um período determinado cronologicamente, uma função desempenhada, ou o envolvimento e a experiência em acontecimentos ou conjunturas específicos. ${ }^{20}$

É importante reiterar que o tratamento das fontes orais requer responsabilidade e rigor metodológico, de modo que os trechos dos depoimentos aqui apresentados - bem como a versão integral das entrevistas reproduzidas no apêndice - foram transcritos e minimamente editados respeitando o seu conteúdo original e mantendo a fidelidade à forma de expressão do pensamento utilizada pelo narrador. ${ }^{21}$ Além disso, como as entrevistas foram realizadas em 2005, entramos novamente em contato com os entrevistados para que eles pudessem revisitar seus relatos, inclusive modificar, acrescentar ou retirar passagens, ${ }^{22}$ e, então, aprová-los para publicação.

$\mathrm{Na}$ ocasião, as entrevistadas nos receberam em suas casas, enquanto a conversa com o vice-prefeito realizou-se em seu gabinete, no prédio da Prefeitura. Nas três situações, não foi pré-determinado um limite de tempo para a duração do encontros, de modo que o ritmo da entrevista obedeceu ao tempo narrativo de cada entrevistado. No mesmo sentido, o recorte temático orientou o enfoque dos relatos, porém buscando preservar a autonomia dos narradores e sua liberdade para direcionar suas rememorações. Essas questões se mostram relevantes na medida em que se compreende a narrativa oral de uma entrevista como o resultado da interação entre entrevistado e

\footnotetext{
${ }^{20}$ ALBERTI, Verena. "Histórias dentro da História”. Op. Cit. p. 175.

${ }^{21}$ Nesse sentido, compartilhamos a perspectiva de Tania Maria Fernandes (Op. Cit., p. 93), segundo a qual "ao manipularmos um depoimento buscando transformá-lo em um texto, além de uma fonte escrita, através de sua transcrição e edição, estaremos sem dúvida alterando-o na sua forma original, porém não necessariamente modificando seu conteúdo (...)”.

${ }^{22}$ Nenhum dos três alterou o conteúdo de seus testemunhos.
} 
entrevistador, em que a fala daquele também depende da circunstância da entrevista e do modo pelo qual ele percebe seu interlocutor. ${ }^{23}$

Nesse momento, passaremos a destacar, dos relatos, alguns pontos que dialogam mais diretamente com o conteúdo exposto, buscando tecer relações entre as narrativas dos entrevistados e o contexto ao qual elas remetem, ou seja, as referidas histórias dentro da história. ${ }^{24}$ Nesse sentido, e em consonância com a proposta do enfoque temático, os trechos dos depoimentos que fazem referência a elementos semelhantes estarão apresentados de maneira agrupada e, quando for o caso, associadas também a citações do próprio Livro Vermelho, com o objetivo de - através da comparação e do entrelaçamento entre as fontes primárias e secundárias - ampliar a compreensão sobre o contexto estudado.

Como já foi mencionado anteriormente, o Brasil, no período de maior influência do Livro Vermelho, vivia sob um regime de ditadura, que começava a tornar-se cada vez mais sólido e mais agressivo, gerando inúmeras manifestações populares contrárias. Outras obras de Mao Tse-tung, como lembrou o vice-prefeito Luciano Siqueira em sua entrevista, já eram conhecidas no país, despertando um interesse geral pela China e pelo pensamento desse 'timoneiro' revolucionário que estava implantando o comunismo naquela distante região.

A maior expressão da Revolução Chinesa era Mao Tsé-tung, que já havia divulgado uma obra relativamente extensa e que, naturalmente, tanto quanto a Karl Marx e Engels e outros autores, despertou, nesse período, uma curiosidade muito grande. ${ }^{25}$

O período conturbado e marcado pelas manifestações estudantis que se desenvolveu no país a partir de 68 foi identificado por Lília Gondim, que ressaltou a peculiaridade desse momento de contestação de valores e exteriorização de sentimentos.

Em 68 houve muitas manifestações por aqui. Houve a história da morte do padre Henrique no começo de 69 também. Essa época foi uma época muito fervilhante de manifestações, de passeatas na rua, de briga com a polícia. Não só aqui, mas no mundo inteiro. ${ }^{26}$

\footnotetext{
${ }^{23}$ ALBERTI. Verena. "Histórias dentro da História”. Op. Cit. p. 171.

${ }^{24}$ É importante ressaltar, entretanto, que a riqueza dos depoimentos na íntegra excede, e muito, os destaques realizados a seguir, razão pela qual considerou-se imprescindível manter aqui os testemunhos completos.

${ }^{25}$ SIQUEIRA, Luciano. Apêndice C.

${ }^{26}$ GONDIM, Lilia. Apêndice B.
} 
Esse também foi um momento de críticas e lutas internas dentro das esquerdas brasileiras, gerando numerosos partidos ou organizações. O PCB estava sendo severamente criticado por continuar a defender uma revolução pacífica e em duas etapas (uma democrática e outra socialista), mesmo após o golpe de 64. A maioria das outras organizações defendia a luta armada, inspirando-se nos modelos da Revolução Russa, Maoísta ou Cubana.

O PC do B, por exemplo, seguia uma estratégia baseada na teoria maoísta da Guerra Popular Revolucionária, que "defendia duas etapas na revolução (antiimperialista e socialista) e a formação de um exército guerrilheiro sob o comando de um partido marxista-leninista." ${ }^{27}$ A AP, uma organização política saída dos setores progressistas ligados à Igreja Católica, seguia uma orientação marxista-leninista que tinha muita influência dos escritos de Mao Tsé-tung, inclusive do Livro Vermelho, conforme atesta Tereza Costa Rêgo: “(...) quase todos tinham grande influência maoísta: os dirigentes, o pessoal que fundou o PCdoB, a AP."28

Dentro desse contexto, o Pequeno Livro Vermelho de Mao se fez presente de uma maneira pouco imaginada pela maior parte das pessoas. Foi impressionante perceber, através das entrevistas, como um livro tão pouco comentado teve tanta participação no cotidiano daqueles que militavam pela implantação do comunismo. Ele ora funcionava como porta de entrada para o pensamento de Mao, ora oferecia normas de conduta para as coisas mais simples.

O Livro parece que tinha resposta para tudo. (...) As frases de Mao tinham muita importância, eram vistas como regras para serem seguidas. ${ }^{29}$

\footnotetext{
${ }^{27}$ PAES, Maria Helena Simões. A década de 60: Rebeldia, contestação e repressão política. $3^{\text {a }}$ ed. São Paulo: Ed. Ática, 1995 (Série Princípios). Pág. 65. Nesse momento, Mao distanciava-se do comunismo soviético, construindo uma ideologia comunista baseada mais nos camponeses do que nos operários urbanos. No Brasil, essa perspectiva moaísta influenciou a organização da Guerrilha do Araguaia, " $a$ mais duradoura e importante experiência de luta armada no campo contra a ditadura militar e um dos mais brutais episódios de repressão a militantes de esquerda e a pessoas comuns no perído". (MECHI, Patrícia. "A Guerrilha do Araguaia e a repressão contra camponeses: reflexões sobre os fundamentos e as práticas repressivas do estado brasileiro em tempos de ditadura". História Revista, v. 20, n. 1, p. 48-70, 2015). Para o Partido Comunista do Brasil, que era alinhado à proposta comunista de Mao, a região de fronteira entre os estados do Pará, Maranhão e Tocantins (à época, norte de Goiás), seria o ponto geográfico ideal para a tentativa concreta de uma revolução comunista no Brasil, por ser uma região em que predominava uma população campesina de analfabetos, lavradores, mineradores. Inclusive, os primeiros candidatos a guerrilheiros que chegaram ao Araguaia tinham passado por um treinamento militar teórico na China de Mao. (ALBERTIM, Bruno. Tereza Costa Rêgo: uma mulher em três tempos. Recife: Cepe, 2018, p. 107).

${ }^{28}$ COSTA RÊGO, Tereza. Apêndice A.

${ }^{29}$ Ibidem.
} 
O Pequeno Livro Vermelho foi um instrumento que acompanhou de perto as nossas manifestações e as nossas ações. Ele tinha ideais muito fortes, pensamentos que realmente marcaram nossas memórias. ${ }^{30}$

(...) o contato com o Livrinho, que era na realidade citações de Mao Tse-tung, interessava muito a nós, sobretudo depois que a Ação Popular resolveu se dividir em 72, e ingressar no PC do B, Partido Comunista do Brasil, que nessa época vivia ainda na clandestinidade. ${ }^{31}$

Todos os entrevistados foram unânimes em ressaltar a presença quase constante do Livro nas reuniões de Partido, nas conversas. Presença essa que era percebida, de acordo com as narrativas, como sendo muito intensa e orientadora das diretrizes e das práticas políticas da militância.

Aqui no Brasil, em qualquer reunião, eles abriam o Livro Vermelho. Era quase um fanatismo. A gente abria até aleatoriamente. Parecia uma Bíblia, como se você tivesse uma mensagem do dia. ${ }^{32}$

(...) todo dia nós líamos o Livro, todo dia pegávamos um textinho daquele para ler; todo dia, todo dia, todo dia. Ele orientava toda a prática do movimento estudantil, e fora do movimento também. (...) Nós líamos para conhecer realmente o pensamento, como funcionava a ideologia. $\mathrm{E}$ os textos, todos os textos partidários sempre se referiam, sempre tinham alguma citação do Livrinho, sempre se referiam a alguma citação do livro. ${ }^{33}$

(...)O Livro Vermelho era como se fosse aquele breviário que os padres tinham, que a pessoa se levanta e lê para se inspirar para aquele dia (...) um companheiro que hoje é do Comitê Estadual do PC do B, do Rio Grande do Sul, esteve numa reunião clandestina aqui em Pernambuco, onde ele abriu esse livrinho no momento em que nós estávamos fazendo um balanço da política, e ele dizia, com um ar de quem havia descoberto a pólvora: "Pô tche! Aqui está dito pelo presidente Mao que a origem de todos os nossos erros está no subjetivismo". ${ }^{34}$

É importante reiterar que, nesse período, em função do alinhamento políticoideológico de grupos e partidos de esquerda, como o PCdoB, ao projeto maoísta, a China estava se tornando a nova referência real do comunismo no mundo, e um dos principais instrumentos desse processo era o Pequeno Livro Vermelho. Nesse sentido,

\footnotetext{
${ }^{30}$ GONDIM, Lilia. Apêndice B.

${ }^{31}$ SIQUEIRA, Luciano. Apêndice C.

${ }^{32}$ COSTA RÊGO, Tereza. Apêndice A.

${ }^{33}$ GONDIM, Lilia. Apêndice B.

${ }^{34}$ SIQUEIRA, Luciano. Apêndice C.
} 
percebe-se como as representações ${ }^{35}$ dos entrevistados acerca da presença dessa publicação em seu cotidiano de militância contribuem para a compreensão da dimensão concreta dessa realidade teorizada pela literatura.

Além disso, o Livro tratava de questões complexas de uma maneira simples, que encontravam muito eco nas pessoas. Muitas de suas passagens ainda estão vivas na memória dos entrevistados.

Uma coisa de que me lembro bem era a ideia de servir. Essa coisa de servir ao povo, muito presente no livrinho de Mao, nos impressionava demais. Esse 'servir ao povo', 'estar a serviço do que interessa ao povo' era uma coisa tão forte que até para atravessar a rua o 'popular' tinha prioridade. Chegava a ser exagero, mas era assim que a sua cabeça funcionava. (...) Até hoje, nas universidades mesmo, você tem a referência dos 'tigres de papel'. Aquela famosa frase 'o imperialismo é um tigre de papel, terrível na aparência, mas na realidade não é tão perigoso assim'. Essa foi uma das ideias que ficou muito marcada na memória. ${ }^{36}$

E conta um deles que o baiano, na fome, lia o Livrinho de Mao Tsetung, dizendo em voz alta: "Ousar lutar, ousar vencer" ${ }^{37}$ ou "as massas é que transformam a sociedade. ${ }^{38}$

\section{Citações do Livro Vermelho:}

Todos os quadros, seja qual for o seu posto, são servidores do povo. Tudo o que fazemos é em serviço do povo. ${ }^{39}$

Todos os reacionários são tigres de papel. Na aparência, os reacionários são terríveis, mas na realidade não são assim tão poderosos. $^{40}$

“O povo, e só o povo, constitui a força motriz nas criação da história universal." $" 41$

“As massas são os verdadeiros heróis (...) As massas populares dispõem de um poder criador ilimitado" 42

A linguagem fácil, o tom "revolucionário" que conclamava para a luta, as críticas ao imperialismo eram características que atraíam os militantes. E como, naquele momento, as notícias que chegavam da China exaltavam a Revolução Cultural, todos

\footnotetext{
35 Nesse sentido, o termo representações remete aos sentidos e significados construídos pelos entrevistados a respeito das experiências que estão sendo narradas.

${ }^{36}$ GONDIM, Lilia. Apêndice B.

37 “Ousar lutar e ousar vencer” é o título do VII capítulo do Pequeno Livro Vermelho, pg.68

${ }^{38}$ SIQUEIRA, Luciano. Apêndice C.

${ }^{39}$ Livro Vermelho. Op. Cit.. p. 125

${ }^{40}$ Idem, p. 62

${ }^{41}$ Idem. p. 91

${ }^{42}$ Idem, p. 91
} 
tinham a sensação de que aquele era um caminho certo, de que os chineses realmente estavam conseguindo construir uma trajetória rumo ao comunismo.

Havia, naquela época, uma mística de que as coisas tinham dado certo, de que a China tinha realmente acertado ${ }^{43}$

Mao Tse-tung era um poeta também (...) ele tinha o dom de escrever sobre coisas complexas de uma maneira simples. ${ }^{44}$

Um texto redigido por Pedro Pomar e publicado, em 1968, pelo jornal clandestino "A Classe Operária", que havia sido relançado em 1962 pelo PC do B, é bastante elucidativo quanto a essa questão:

\begin{abstract}
As vitórias da Revolução Cultural Proletária na China constituem valioso alento à luta da classe operária e dos povos oprimidos por sua independência, pela democracia e o socialismo. Significam, ao mesmo tempo, contundente derrota para a coalizão mundial contrarrevolucionária do imperialismo, da reação e do revisionismo contemporâneo. (...) Os comunistas brasileiros, que receberam com entusiasmo os grandes êxitos da Revolução Cultural Proletária, procuram estudar seus ensinamentos e divulgar suas experiências. Ao mesmo tempo, erguem, cada vez mais alto, a bandeira vermelha do pensamento de Mao Tsé-tung, que descortina para nosso povo o caminho da revolução e da guerra revolucionária de libertação. ${ }^{45}$
\end{abstract}

O Pequeno Livro Vermelho não podia acompanhar os militantes em suas passeatas, sob o risco de serem presos e facilmente incriminados por portarem "material subversivo", mas isso não impedia que ele estivesse presente na mentalidade e nas ações; além disso, o acesso a ele era facilitado pelas próprias organizações (o PC do B, a $\mathrm{AP})$.

Levávamos [o livro] mais na cabeça do que na mão. ${ }^{46}$

Nós recebíamos [os livros] do Partido, eles eram doados ou vendidos muito barato. $^{47}$

Ele [o livro] era vendido nas livrarias, era vendido ali na Imperatriz.

(...) Ele podia ser vendido mas, por exemplo, se você fosse preso e a polícia fosse na sua casa e encontrasse o livro, era uma forma de lhe

\footnotetext{
${ }^{43}$ COSTA RÊGO, Tereza. Apêndice A.

${ }^{44}$ SIQUEIRA, Luciano. Apêndice C.

45 "Grandes êxitos da Revolução Cultural". Documento redigido por Pedro Pomar, publicado em A Classe Operária, órgão central do PCdoB, 1968.

${ }^{46}$ GONDIM, Lilia. Apêndice B.

${ }^{47}$ COSTA RÊGO, Tereza. Apêndice A.
} 
incriminar.... Foi uma das contradições da ditadura: a venda não era proibida, mas era proibido ter. ${ }^{48}$

Ele circulava quase clandestinamente. Eu não sei em que época ele passou a ser editado. ${ }^{49}$

Fazendo um balanço daquele momento, os entrevistados relataram suas impressões pessoais e conclusões sobre a influência do Livro Vermelho (em suas vidas, no movimento, no pensamento de esquerda).

Acredito que, por um lado, teve um ponto muito positivo. Era como se fosse um caminho que você seguisse e estava ali sempre orientado. Talvez até tivéssemos supervalorizado [o livro], mas é uma supervalorização de coisas que não são ruins para nós, não são valores que pesem de forma ruim pra gente, são valores bons, que nos tornam melhores. ${ }^{50}$

Eu acredito que esse tipo de obra, ao invés de ser útil à compreensão da teoria, e ao entendimento dos processos históricos, termina sendo nocivo. Hoje eu tenho essa opinião. O que há aqui [no Livro Vermelho] é uma coletânea de trechos dos diversos episódios, arquivos e textos de Mao Tsé-tung. Embora alguns pedaços deles digam a data e do que se trata, (palestra à escola tal, entrevista à jornalista fulana de tal...) é muito difícil contextualizar as informações. (...) Isso leva o povo, grande parte, senão a maioria, a uma compreensão simplista da realidade e dos processos de transformação da sociedade. (...) Aqui [no Livrinho] tem muitas frases elogiando a simplicidade, que estimularam, uma atitude mais humilde, a cooperação, a solidariedade, a confiança no povo, a confiança no porvir histórico. Isso tudo ajudou muito, é um aspecto que não pode ser negado. Eu acredito que cumpriu um certo papel. Ora, você imagine chegar no alto de uma serra, no meio do mato, para se reunir escondido do governo e encontrar trabalhadores rurais, semianalfabetos, abrindo um livrinho daquele, lendo com dificuldade, depois de terminar o trabalho na roça. ${ }^{51}$

É importante pontuar que nem sempre os fragmentos narrativos destacados foram convergentes na forma de descrever as vivências ou tecer opiniões acerca do Livro Vermelho, de modo que é possível identificar contradições ou pontos de vista distanciados entre alguns depoimentos. No entanto, essas diferenças nos relatos remetem justamente ao caráter múltiplo das narrativas, as quais não devem ser entendidas como retratos objetivos do passado, mas como sentidos conferidos às experiências no momento em que são narradas. Essas construções possibilitam

\footnotetext{
${ }^{48}$ GONDIM, Lilia. Apêndice B.

${ }^{49}$ SIQUEIRA, Luciano. Apêndice C.

${ }^{50}$ GONDIM, Lilia. Apêndice B.

${ }^{51}$ SIQUEIRA, Luciano. Apêndice C.
} 
"visualizar somente uma perspectiva específica da realidade: aquela construída pelo narrador ${ }^{, 52}$.

A análise das entrevistas realizadas poderia privilegiar vários outros aspectos das vivências narradas, tendo em vista a riqueza de tais fontes. $\mathrm{O}$ presente artigo, no entanto, realizou recortes temáticos com vistas a explorar experiências de um contexto específico - a presença do Pequeno Livro Vermelho na luta contra a ditadura militar no Recife.

${ }^{52}$ ALBERTI, Verena. "Histórias dentro da História”. Op. cit., p. 170. 


\section{APÊNDICE A - Entrevista 1}

\section{TEREZA COSTA RÊGO ${ }^{53}$}

"Eu fui militante durante muito tempo, cheguei até a viver na clandestinidade. Eles me chamavam de camarada Joanna. Como membro do Partido, eu tinha que fazer o que eles orientavam... até a minha tese de doutorado foi orientada pelo Partido, pois eu gostaria de ter feito algo relacionado à arte, mas fiz uma tese sobre a história do proletariado brasileiro.

Eu tenho, e sempre tive, um fascínio muito grande pela China. Eu estava em São Paulo e fui a primeira vez à China em plena Revolução Cultural. Eu vi na China a mudança política. O PCdoB era um partido pequeno, mas mesmo assim eles recebiam os presidentes de partido como se fossem presidentes da República. Eles nos tratavam muito bem!!! Iam nos buscar no aeroporto; não enfrentamos fila para nada, não passamos nem pela alfândega. Eles tinham um cuidado danado!

Nós passeamos muito, fomos para todos os lugares, visitamos várias regiões da China, conhecemos tudo. Era um culto à personalidade de Mao demasiado. Eles mostravam a cama de Mao, os lugares por onde Mao, Chu En-Lai passaram, etc. Eu fui a muitas cooperativas, cooperativas de artesanato, de pintura. A pintura era muito panfletária, sempre mostrando o ambiente rural, os camponeses felizes, trabalhando. Foi de lá que eu trouxe esses dois catálogos com pinturas de artistas das cooperativas. Algumas pinturas estão inclusive assinadas pelos seus autores. Uma delas mostra a figura do "médico de pés descalços", uma espécie de agente de saúde, de enfermeiro, que ia nas casas tratar das pessoas; eles também retrataram bastante o "jornal-mural", onde eram colocadas as notícias do dia, e as pessoas se aglomeravam em volta para olhar.

O povo era muito camponês. Eu não vi miséria nos lugares por onde passei; ainda havia pobreza, mas miséria mesmo, do jeito que a gente tem aqui no Brasil, eu

\footnotetext{
${ }^{53}$ COSTA RÊGO, Tereza. Entrevista 1. [fev. 2005]. Entrevistadoras: Raquel Torres e Juliana Beserra. Olinda, 2005. A entrevista com Tereza Costa Rego, por problemas técnicos e pela própria vontade da entrevistada, não pôde ser gravada. O texto é um resumo da conversa transcrita através das anotações das autoras.
} 
não vi. Todos os camponeses tinham suas roupas, suas vestimentas, até porque lá é muito frio.

Lá eu assisti a várias manifestações, e fiquei muito impressionada... aqueles homens balançando o livro na rua... Era igualzinho a uma cena que tem no filme "O último imperador", com os soldados andando pelas ruas, sacudindo o livro... os incriminados com aqueles chapéus em forma de cone, com o crime escrito no papel, pra todo mundo ver. Era exatamente daquele jeito que o filme mostrou. Aqui no Brasil, em qualquer reunião, eles abriam o Livro Vermelho. Era quase um fanatismo. O Livro parece que tinha resposta para tudo. A gente abria até aleatoriamente. Parecia uma Bíblia, como se você tivesse uma mensagem do dia. As frases de Mao tinham muita importância, eram vistas como regras para serem seguidas. Nós recebíamos [os livros] do Partido, eles eram doados ou vendidos muito barato.

A última vez que eu fui a China, foi em torno de 75/76, depois da Camarilha dos Quatro. Havia, naquela época, uma mística de que as coisas tinham dado certo, de que a China tinha realmente acertado.

Por isso, quase todos tinham grande influência maoísta: os dirigentes, o pessoal que fundou o PCdoB, a AP. A geração dos velhos era muito stalinista, até terem notícia do que Stálin realmente tinha feito na Rússia, afinal, naquela época, essas notícias não eram divulgadas, só chegaram depois.

Quando houve a anistia política, eu e meu marido pudemos voltar para o Brasil, mas assim que nós colocamos o pé aqui, ele teve um ataque cardíaco. Foi ali que eu resolvi me dedicar definitivamente à pintura, coisa que faço até hoje." 


\section{APÊNDICE B - Entrevista 2}

\section{LÍLIA GONDIM ${ }^{54}$}

"O Pequeno Livro Vermelho foi um instrumento que acompanhou de perto as nossas manifestações e as nossas ações. Ele tinha ideais muito fortes, pensamentos que realmente marcaram nossas memórias. Uma coisa de que me lembro bem era a idéia de servir. Essa coisa de servir ao povo, muito presente no livrinho de Mao, nos impressionava demais. Esse 'servir ao povo', 'estar a serviço do que interessa ao povo' era uma coisa tão forte que até para atravessar a rua o 'popular' tinha prioridade. Chegava a ser exagero, mas era assim que a sua cabeça funcionava. O 'servir' se manifestava até nessas coisas pequenas.

Quando a minha primeira filha nasceu, em 73, eu contava histórias para ela, inventava histórias para contar baseadas nessas coisas. Eu me lembro de uma história, que tinha no livro, que eu costumava contar, de um velho que cavava uma montanha, e seu filho vinha lhe perguntar por que ele fazia isso se o esforço era inútil, pois a montanha não sairia dali; no que o velho respondia 'meu filho, se você cavar um pouquinho todos dos dias a montanha pode ser removida'. Isso mostra como a coisa era muito presente.

Até porque todo dia nós líamos o Livro, todo dia pegávamos um textinho daquele para ler; todo dia, todo dia, todo dia. Ele orientava toda a prática do movimento estudantil, e fora do movimento também.

Ele [o livro] era vendido nas livrarias, era vendido ali na Imperatriz. Não era escondido, a venda não era proibida, mas se você tivesse em casa... Ele podia ser vendido mas, por exemplo, se você fosse preso e a polícia fosse na sua casa e encontrasse o livro, era uma forma de lhe incriminar.... Foi uma das contradições da ditadura: a venda não era proibida, mas era proibido ter.

Era uma coisa muito forte, uma presença muito marcante na prática das coisas. Eu me lembro de uma vez, já no auge na repressão, quando fui passar, em 74, o

\footnotetext{
${ }^{54}$ GONDIM, Lília. Entrevista 2 [mar. 2005]. Entrevistadoras: Raquel Torres, Juliana Beserra e Elaine Cunha. Olinda, 2005. 01 Fita Cassete.
} 
carnaval na Bahia. Eu e meu marido ficamos num apartamento de um pessoal que estava fora, viajando. Quando chegamos, ficamos um pouco chocados porque não havia nada... não tinha comida, a geladeira estava seca porque o pessoal estava fora... só tinha uma estante de livros e um colchão no chão. Ma estava tudo bem, porque só íamos usar o apartamento para dormir. Estávamos até meio chateados pensando se não havia nada para fazer ali. Começamos a olhar os livros e encontramos as citações de Mao Tse-tung. Pronto, já tínhamos o que fazer! Foi um barato, porque desde 70, (eu passei o ano de 70 todo presa), que eu não via, não pegava no livro. Eu tinha ele, mas quando eu fui presa a polícia foi na minha casa, e meus pais deram fim em tudo o que deviam dar e tudo o que não deviam. Não sabiam distinguir o que era perigo e o que não era, então acabaram com tudo. Muitos livros interessantes que eu tinha, de Engels, eles deram fim. E meu livro de Mao Tse-tung foi no meio.

$\mathrm{E}$ assim, desde 70 eu não pegava num livro daquele. E quando eu vi pensei que poderia passar o carnaval todinho só lendo. Fiquei muito feliz quando vi o livro. Nós líamos para conhecer realmente o pensamento, como funcionava a ideologia. E os textos, todos os textos partidários sempre se referiam, sempre tinham alguma citação do Livrinho, sempre se referiam a alguma citação do livro.

O pequeno Livro Vermelho falava muito da questão da ambientação rural dos chineses, dos camponeses, o peso do camponês dentro dessa luta. Nessa época já não estávamos mais no período das ligas camponesas por aqui, portanto não pegávamos o livro ao pé da letra. E o livro, como vocês conhecem vocês devem saber, se refere muito mais ao camponês por conta da população chinesa, que era predominantemente rural. Mas o que nós tirávamos dali eram as idéias mais filosóficas, mais gerais. Porque ele sempre, mesmo que ele contasse, mesmo que o textinho contasse uma história específica chinesa, ele sempre generalizava, colocava coisas do ideológico, do pensamento. Conseguíamos fazer a diferenciação.

Até hoje, nas universidades mesmo, você tem a referência dos 'tigres de papel'. Aquela famosa frase 'o imperialismo é um tigre de papel, terrível na aparência, mas na realidade não é tão perigoso assim'. Essa foi uma das idéias que ficou muito marcada na memória. Costumávamos até brincar porque o símbolo da Esso era um tigre, e dizíamos 'Olha aí, tá vendo, o tigre de papel do imperialismo ali'. 
[Entrevistador]: A senhora chegou a ver, em alguma manifestação popular, as pessoas carregando o livro?

Não. Aqui em Pernambuco mesmo eu não vi acontecer isso. Pelo menos nas passeatas de que eu participei, não lembro de ninguém levando na mão. Levávamos mais na cabeça do que na mão. Podiam até levar, mas eu não me lembro de ter visto. Porque era uma coisa muito preciosa. A gente não gesticulava muito com ele, até para não tomarem.

[Entrevistador]: A senhora poderia nos contar um pouco de sua trajetória no movimento estudantil?

Eu estudei, durante o primeiro grau todo, em uma escola de freiras, que era muito superprotetora. Eu não sabia de nada, não tinha conhecimento de nada do que acontecia do lado de fora, porque colégio de freiras é superprotetor.

Quando saí eu fui para o Colégio Estadual do Recife, fazer o segundo grau, e lá, eu me choquei com a realidade do que é realmente o ensino público do Brasil. Você chega lá e o professor faltou ou não tem giz pra escrever; e você sente a questão das pessoas que precisam entrar e não podem porque não tem mais vaga, e que precisam estudar ali porque não têm como pagar. Isso começou a me chamar a atenção.

Na minha sala, eu fiquei muito próxima de algumas pessoas que faziam parte do Diretório, então fui começando a participar desse Diretório, que na época se chamava Grêmio Estudantil. Comecei a ler, comecei a participar de manifestações na rua e reuniões com pessoas de movimento estudantil de outras escolas. Assim eu entrei no movimento estudantil.

Isso foi em 67. Em 68 houve muitas manifestações por aqui. Houve a história da morte do padre Henrique no começo de 69 também. Essa época foi uma época muito fervilhante de manifestações, de passeatas na rua, de briga com a polícia. Não só aqui, mas no mundo inteiro. Aqui eu lembro de brigas terríveis, que eu contava pros meus filhos e eles ficaram espantados, sem acreditar. Brigas de a gente ir para a rua com bolinhas de gude, para sacudir no chão e fazer os cavalos escorregarem. Jogávamos bolinha de gude no capacete dos soldados, porque fazia uma barulho infernal, o soldado ficava louco e tirava o capacete. 
Eu me lembro de uma cena no Mercado de São José. Estava havendo um comício relâmpago por ali, que acontecia quando nos juntávamos rapidamente num ponto, geralmente um ponto muito fervilhante de camelôs, alguém fazia um discurso 'contra a ditadura', 'contra a repressão', e ia embora. Tinha que ser rápido, porque a polícia chegava rapidinho.

Em uma das vezes a polícia chegou, nós começamos a correr por dentro do mercado São José, e um rapaz que passou derrubou uma saca de feijão, fazendo com que os soldados fossem escorregando, caindo por causa das botas, e nos permitindo correr. Na época também havia um apoio muito grande da população, de um modo geral.

Uma vez a gente estava ali, em uma daquelas ruas cheias de camelôs que dão no Mercado São José. Tadeu (que hoje é chefe de gabinete do vice-prefeito) estava carregando os panfletos, que nós distribuíamos e voltávamos para pegar mais. Ele era o estoque. De repente, chegou um policial e quis leva-lo preso. Ele, então, pegou o pacote de panfleto e jogou nos peitos do policial e saiu correndo. Entrou em uma daquelas lojas que vendem tecido e se escondeu debaixo de um daqueles tabuleiros. Um dos funcionários da loja apontou, o policial veio, pegou ele, levou preso e cometeu o erro de voltar pelo mesmo caminho. Os camelôs fizeram um cerco e começaram: 'Se ele está preso, eu estou' 'Se ele está preso, eu estou'. Assim, Tadeu pôde fugir e o soldado ficou lá. Isso mostra o apoio popular grande.

Posteriormente, em 69, houve a visita de Rockfeller, uma das maiores fortunas do mundo. Ele veio visitar Pernambuco e o movimento estudantil organizou uma pixação geral na rua: FORA ROCKFELLER. Era só isso, e em alguns lugares ABAIXO O IMPERIALISMO. Eu fazia parte de um dessas equipes, que era composta por cinco pessoas; nós pegamos aquela área da rua Imperial, onde hoje passa o viaduto para Boa Viagem, que na época era muito movimentada. Aquele ponto era de muito movimento, todos os ônibus que vinham de lá, daquela parte, passavam por ali.

Começamos pixar as paredes, e os ônibus também, porque eles circulam. Foi aí que fomos presos. O nosso grupo foi preso e só escapou um; os outros foram todos presos. Passamos uns dias, fomos para o julgamento e, depois da sentença, pegamos um ano, por um artigo ridículo que tem: 'Atentado a uma nação amiga'. Nada a ver!! 
Atentado a uma nação amiga é demais, não é? Então ficamos um ano preso e depois, em 72, quando eu estava grávida da minha primeira filha, eu fui presa de novo, e dessa vez foram me buscar em casa.

Nessa primeira vez não houve tortura, apenas 'empurra para lá', 'empurra para cá', grosseria. Mas a segunda vez, aí sim, eu levei choque, e estava apavorada, porque estava grávida e ainda não aparecia a gravidez. E eu estava com medo de dizer que estava grávida, porque era uma faca de dois gumes. Ou eles teriam cuidado, ou podiam me ameaçar de fazer abortar. Então eu não dizia nada. Levei choque, muita pancada na barriga, porque não ficava marca, não dava para aparecer. Eu fiquei apavorada, mas não perdi não. Hoje eu já tenho até neto.

Essa prisão foi daquelas prisões do DOI-CODI, dos anos 70, onde eles queriam saber alguma coisa, então pegavam, pressionavam, pressionavam, pressionavam, você nunca sabia de nada, e depois eles soltavam. Quando eles me soltaram, eu morava ali no IPSEP, naquele conjunto da SUDENE, (minha mãe ainda mora láP. E quando eles me soltaram, eles me levaram vendada, me tiraram do carro e me soltaram ali naquele trecho entre a CEASA e a entrada de Jardim São Paulo. Era de noite e eu vim correndo. E naquela época não tinha o movimento que tem hoje, e nem a violência, mas de qualquer forma era perigoso, pois estava-se sujeito até a eles mesmos voltarem e darem um tiro por trás, e ninguém ficar sabendo.

[Entrevistador]: Depois que passou tudo isso, você voltou a fazer essas leituras?

Não, toda vez que eu tenho a oportunidade eu leio. O de Mao não, porque eu perdi e não tive mais a chance de recupera-lo. Eu tenho o outro livrinho dele, que é a respeito da filosofia de Mão Tse-tung, mas não é o Livro Vermelho, é outro. Mas eu sempre leio. Eu tenho uma coleção completa de Marxismo. De vez em quando eu dou uma olhadinha. E como eu fiz Economia, em Economia a gente utiliza muito o marxismo, a questão das leis marxistas da área de produção, economia, de forma de produção.

[Entrevistador]: Como a senhora avalia hoje toda essa moda, essa construção que foi feita na época sobre o maoísmo? Seria supervalorização? 
É. Talvez até possamos avaliar como supervalorização, mas para a gente não era não. Para nós era o dia-a-dia mesmo, sempre estávamos usando as citações. Acredito que, por um lado, teve um ponto muito positivo. Era como se fosse um caminho que você seguisse e estava ali sempre orientado. Talvez até tivéssemos supervalorizado, mas é uma supervalorização de coisas que não são ruins para nós, Não são valores que pesem de forma ruim pra gente, são valores bons, que nos tornam melhores.

Por isso eu acho que valeu a pena, acredito que foi muito interessante esse período, foi um momento muito rico. Por exemplo, a geração dos meus filhos é uma geração diferente da minha, da parte da minha geração que viveu esse tipo de coisa. Nós temos uma forma de raciocinar e de pensar sobre determinadas coisas diferente. Não só em termos políticos, mas em termos de cultura. É diferente, eu realmente acho que valeu a pena. Muitas pessoas que viveram a época com a gente diziam que isso era besteira de adolescente, mas eu não concordo com isso. Acredito que teve um peso muito grande. É verdade que tive um ônus muito grande também,principalmente da perda de companheiros, mas eu acho que foi a junção de todas essas manifestaçõezinhas, que ocorreram no país inteiro, que provocaram as mudanças que hoje a gente tem. Não é ideal mas, pelo menos, já abriu muitos espaços que não tínhamos antes.

A diferença, para mim, é que a gente brigava mais porque era proibido. Hoje você pode querer ser comunista e dizer que é comunista; Hoje o Partido Comunista é legal, e é muito legal ser comunista. Mas, naquela época, era uma coisa mais forte, porque você tinha que fazer isso brigando com todo mundo, inclusive com a sua família. Até em casa, havia briga para sair, porque tinham o medo de que você fosse presa.

Eu me lembro de que uma vez que eu fugi de casa e disse 'não volto mais', porque não tinha liberdade, não podia ir para canto nenhum; as pessoas tinham medo de eu ser presa. É claro que, em casa, nãome prendiam por mau, me prendiam para me proteger. No entanto para mim aquilo era uma coisa terrível.

Eu acho que por isso as pessoas naquela época eram muito mais unidas. Independente de facção. Por exemplo, um grande amigo meu, acho que meu maior amigo daquela época, era de outro partido. Era Ramires, que foi assassinado pela repressão no Rio. A nossa facção era 'vanguarda', a dele era 'opinião', todos os dois 
eram de esquerda, mas tinha briga. Só que todo mundo era muito amigo. Não é como hoje.

Hoje eu vejo, no movimento estudantil, lá na Federal, o pessoal intrigado mesmo. Brigam, discutem, só faltam ir às tapas. Nós, quando chegávamos numa assembleia, discutíamos politicamente, nos escutávamos, gostávamos uns dos outros, saíamos juntos, éramos amigos. E eu acredito que foi mais por conta dessa questão do medo que vivemos juntos, que nos tornamos muito próximos.

Esse menino, Ramires, fazia parte do nosso grupo quando fomos presos. Ele foi o único que escapou porque nós protegemos a fuga dele, porque ele era um cara que estava procurado, que já estava ameaçado de morte; então era pior, se ele fosse preso ele ia morrer. Então protegemos a fuga dele, porque apesar de ele ser de outro partido, de outra facção, era um companheiro na hora de brigar. Eu acho que isso era uma coisa muito boa, que hoje em dia não existe mais." 


\section{APÊNDICE C - Entrevista 3}

\section{LUCIANO SIQUEIRA ${ }^{55}$}

"Na verdade, o meu contato com o Livro Vermelho começou ainda durante o primeiro ano do curso de medicina, na Universidade federal de Pernambuco. Eu não sou daqui, sou de Natal, e ainda como estudante ocorreu um movimento contra o aumento das tarifas de ônibus, no qual eu me envolvi junto com o alunado todo, e nós passamos o dia na rua. A decisão sobre o assunto era do governador, que recebeu uma comissão de alunos, e me impressionou o fato de os estudantes conseguirem barrar o aumento das passagens. Ali eu fiz duas descobertas muito importantes: uma foi perceber a importância de se lutar por algo que era de interesse comum, e não meramente individual; e a outra foi uma coisa ótima para a minha vida, porque eu descobri que um tímido (e eu sou a pessoa mais tímida que existe na face da Terra e hoje não tenho mais como me curar), participando da luta coletiva, ele não se dilui, não desaparece, mas ganha importância na medida em que ajuda a construir algo maior, junto com outras pessoas.

Depois disso eu vim morar no Recife, quando Miguel Arraes ainda era prefeito. Eu me tornei voluntário do Movimento de Cultura Popular, onde atuava no programa coordenado por uma pedagoga recém-formada, Silke Weber, que anos depois veio a ser Secretária de Educação no segundo governo de Miguel Arraes. O grupo tinha a preocupação de discutir o futuro do Brasil. E uma vez entrando na Faculdade de Medicina, já desde o primeiro ano, eu pertenci ao Diretório Acadêmico. Em 69 eu fui cassado, fui proibido de estudar em qualquer universidade pública ou privada por 3 anos, por ser considerado opositor do Regime Militar. Não demorou muito e eu tive que fugir daqui porque minha namorada, que é minha companheira até hoje, chegou a ser perseguida na rua por policiais. Fomos, então, viver como vendedores ambulantes, com identidades falsas, pelo interior do Nordeste, até que eu fosse preso em abril de 74 .

Depois da cadeia retornei à faculdade e fui aluno de colegas que tinham estudado comigo...E minha vida é esta, de lá para cá, nunca parei de lutar. Já fui deputado estadual duas vezes, virei vice-prefeito da cidade do Recife três vezes, e agora,

\footnotetext{
55 SIQUEIRA, Luciano. Entrevista 3. [mar. 2005]. Entrevistadoras: Raquel Torres e Juliana Beserra. Olinda, 2005. 01 Fita Cassete. Alguns trechos da entrevista tiveram que ser adaptados por conta de problemas na fita transcrita.
} 
tenho mais quatro anos. Em 67, na Faculdade de Medicina, eu entrei em contato uma organização revolucionária chamada Ação Popular. A Ação Popular aderiu ao Partido Comunista do Brasil (PCdoB), e a nível teórico, naquela ocasião, havia uma polêmica muito acirrada entre os marxistas chineses e os soviéticos sobre o rumo das nações socialistas, que ficou conhecido como conflito sino-soviético.

A maior expressão da Revolução Chinesa era Mao Tsé-tung, que já havia divulgado uma obra relativamente extensa e que, naturalmente, tanto quanto Karl Marx e Engels e outros autores, despertou, nesse período, uma curiosidade muito grande. E, portanto, o contato com o Livrinho, que era na realidade citações de Mao Tse-tung, interessava muito a nós, sobretudo depois que a Ação Popular resolveu se auto extinguir em 72, e ingressar no PC do B, Partido Comunista do Brasil, que nessa época vivia ainda na clandestinidade.

Então, é dessa época o contato com as obras de Mao Tse-tung. O Livro Vermelho era como se fosse aquele breviário que os padres tinham, que a pessoa se levanta e lê para se inspirar para aquele dia. Ele circulava quase clandestinamente. Eu não sei em que época ele passou a ser editado. E ele era um exemplar um pouquinho menor e mais gordinho. Então, você andava com ele, carregava dentro do bolso e era fácil de esconder. Provavelmente, na minha casa, quando a polícia chegou lá, levou algumas obras e é provável que tenha levado esse livrinho também.

E por esse período da ditadura, 66/67, é que se deu a Revolução Cultural, um movimento, segundo diziam, destinado a tentar apressar a redução de uma defasagem que é natural entre as transformações da base econômica da sociedade, e as transformações da consciência social. A sociedade chinesa viveu milênios sob o feudalismo, mesclado com resquícios da sociedade escravista, e depois disso, sob o capitalismo, cujo vetor é o interesse da satisfação do ser humano individual. Enquanto o capitalismo busca o lucro máximo como objetivo estrutural, o socialismo busca captar sobretudo as necessidades materiais e individuais de todos. Apesar disso, demora muito para se formar uma consciência socialista, mesmo depois de o país estar vivendo sob uma economia predominantemente socialista. O Livrinho influenciou também na Revolução Cultural os Guardas Vermelhos, além de Esse também inspirar uma espécie de culto a Mao. 
Os chineses pensaram em dar um salto à frente na Revolução Cultural, para tentar apressar algo que hoje nós sabemos demorar um século ou mais, e isso é uma coisa que não se resolve facilmente.... São necessários inclusive milênios, em determinadas transformações. Um século na História é quase nada, não é verdade??

Nós não imaginávamos, naquela época, que o processo da Revolução Cultural, inclusive do ponto de vista das relações de poder e sociais na China, tivesse sido uma onda de radicalismos, de dirigismo estatal, das pessoas, das artes e da produção do período. Ao invés de um salto à frente, hoje eu tenho essa opinião, foi um retrocesso temporário no processo de transformação da China, e que tanta curiosidade e interesse despertaram através das obras de Mao Tse-tung. Muita coisa é importante e é válida, especialmente porque se formulava uma concepção de socialismo segundo as peculiaridades chinesas, sem reproduzirem nenhum modelo de país.

Era natural que nós todos da Ação Popular que aderiu a esse entusiasmo, entrássemos em contato com o Livrinho de Mao Tse-tung. Eu acredito que esse tipo de obra, ao invés de ser útil à compreensão da teoria, e ao entendimento dos processos históricos, termina sendo nocivo. Hoje eu tenho essa opinião. O que há aqui [no Livro Vermelho] é uma coletânea de trechos dos diversos episódios, arquivos e textos de Mao Tsé-tung. Embora alguns pedaços deles digam a data e do que se trata, (palestra à escola tal, entrevista à jornalista fulana de tal...) é muito difícil contextualizar as informações.

Isso leva o povo, grande parte, senão a maioria, a uma compreensão simplista da realidade e dos processos de transformação da sociedade. Às vezes nós nos encontramos nos congressos do Partido ou os Encontros Nacionais, e fazemos piadas ou nos divertimos com as reminiscências daquele momento. Muitos dos membros do PC do B hoje, inclusive alguns da Direção Nacional, são oriundos da Ação Popular e viveram esse período. Eu me recordo de coisas como, por exemplo, esses dois fatos: um companheiro que hoje é do Comitê Estadual do PC do B, do Rio Grande do Sul, esteve numa reunião clandestina aqui em Pernambuco, onde ele abriu esse livrinho no momento em que nós estávamos fazendo um balanço, e ele dizia, com um ar de quem havia descoberto a pólvora: "Pô tche! Aqui está dito pelo presidente Mao que a origem de todos os nossos erros está no subjetivismo", ou seja, numa apreciação da realidade 
não como ela é, mas como a idealizamos. Veja como esse tipo de literatura leva as pessoas a desviarem-se da realidade concreta dos fatos.

Há outro caso de dois companheiros que viviam aqui no Recife, numa situação muito difícil, pois estavam desempregados. Um deles, um baiano, havia sido operário da Microlit (hoje a Rayovac) vivendo com nome falso para organizar o trabalho operário. E o outro era goiano e fazia biscate. Lhes faltou comida porque eles ficaram desempregados, e haviam perdido o contato com o Partido para receberem algum tipo de ajuda. Na fome, eles visitaram uma padaria em Afogados e se apresentaram à padaria como vizinhos de uma velhinha doente, cujo médico havia prescrito farinha de pão. Em casa eles só tinham água da torneira e ki-suco. $\mathrm{O}$ dono da padaria foi muito solidário com a suposta velhinha, e trouxe um saco cheio de pães, mas ao chegar em casa eles descobriram que o pão era duro, duro, tão duro a ponto de eles pegarem uma haste metálica para quebrar o pão, para depois colocar de molho na água e poder comer. E conta um deles que o baiano, na fome, lia o Livrinho de Mao Tse-tung, dizendo em voz alta: "Ousar lutar, ousar vencer" ou "as massas é que transformam a sociedade". Ele gritava e dizia assim: "Companheiro, nós temos que ler Mao Tse-tung para manter a chama acesa, para mantermos o nosso espírito revolucionário. A fome não é nada." Então o outro dizia: "Você está louco, nós vamos acabar morrendo aqui! Vamos para a rua, vamos buscar emprego! Nós precisamos sobreviver!"

De fato, o Mao Tse-tung era um poeta também. Ele formulava as coisas, ele tinha o dom de escrever sobre coisas complexas de uma maneira simples. Havia também esse aspecto, digamos, mais folclórico, mais curioso, de como nós militantes, sobretudo os mais jovens, aderimos a esse pensamento de Mao Tse-tung e acreditamos que aqui estava a posição da vanguarda. Aqui [no Livro Vermelho] não, mas nos textos dele tem muita coisa válida, se contextualizadas do ponto de vista da realidade da sociedade chinesa, do ponto de vista teórico, até universal.

No entanto há um outro aspecto que eu considero importante registrar aqui, que é esse aspecto político. Se uma organização adere à contribuição teórica de um partido, de um povo, de um movimento que aconteceu na Ásia, de uma maneira acrítica, embora isso não esteja de uma maneira tão explícita, é como se ali estivesse um modelo de revolução. Isso tem a ver, do ponto de vista teórico e à luz do marxismo, com o que nós 
chamamos de transposição mecânica de experiências, sistematizações de uma outra realidade, de uma outra estrutura, formação histórica.

Nem nos cabia o perfil da União Soviética, nem o da China. Cabia tomar as experiências desses países e de outros povos, mas sobretudo, aprofundar o estudo da formação econômica, histórica, social, cultural e da realidade do nosso próprio país.

Do ponto de vista teórico da organização partidária revolucionária, essa influência chinesa, dos textos chineses e do Livro Vermelho em especial, era interessante por um lado, mas por outro limitava. Aqui [no Livrinho] tem muitas frases elogiando a simplicidade, que estimularam, uma atitude mais humilde, a cooperação, a solidariedade, a confiança no povo, a confiança no porvir histórico. Isso tudo ajudou muito, é um aspecto que não pode ser negado. Eu acredito que cumpriu um certo papel. Ora, você imagine chegar no alto de uma serra, no meio do mato, para se reunir escondido da polícia e encontrar trabalhadores rurais, semi-analfabetos, abrindo um livrinho daquele, lendo com dificuldade, depois de terminar o trabalho na roça.

Do ponto de vista do PC do B, percebe-se que essa foi uma influência especial, momentânea. O PC do B também teve influência chinesa, mas isso não nos impediu de nos aprofundar nessa visão de que não há modelos aplicáveis. Eu diria também que, quando nós da AP entramos em contato com essa visão crítica, no primeiro momento, foi um choque (embora seja um choque positivo), pois essa opinião mais firme, mais madura, nos levou a uma maior compreensão da realidade.

Hoje, tanto tempo depois eu posso ver as coisas com mais clareza. A Revolução Cultural demonizou, renegou, afastou dos cargos vários de seus antigos funcionários. Um deles, o Deng Chiao-Ping, foi afastado temporariamente porque se opunha à Revolução Cultural, numa postura correta, afinal aquilo era uma coisa mecanicista, destruidora, que virou um jogo de massa na China. Eles faziam perseguição aos universitários supostamente contrários à orientação da Revolução Cultural, colocavam aqueles chapéus grandes, fantasias de palhaços e outras humilhações. Só posteriormente ficou claro que esse sistema, que segundo eles deveria apressar a redução da defasagem estava equivocado, e é depois disso que a China então desenvolve essa compreensão. Isso é tão complexo, do ponto de vista ocidental, que os chineses dizem ainda viverem numa fase preliminar, no início da transição do capitalismo para o socialismo. 
Porque, se hoje é verdade que na China a área da alta tecnologia já domina a tecnologia da guerra nas estrelas, interplanetária, é verdade também que boa parte da economia chinesa é agrária, e a sua consistência no campo é baseada na economia familiar. Num país imenso como aquele, com uma população de Um Bilhão e Trezentos milhões de habitantes, a transformação da sociedade não é uma coisa fácil. Tudo isso é algo muito distante do voluntarismo que salta aos olhos do maoísmo, e desses pensamentos encontrados nas diversas obras do autor.

\section{Referências Bibliográficas}

ALBERTI, Verena. "Histórias dentro da História". In: PINSKY, Carla Bassanezi (Org.). Fontes históricas. São Paulo: Contexto, 2008.

ALBERTIM, Bruno. Tereza Costa Rêgo: uma mulher em três tempos. Recife: Cepe, 2018

"Chiara Lubich e a sua obra pelos direitos dos indivíduos e dos povos (notas biográficas)". Disponivel em: www.focolare.org/br/default.htm

FERNANDES, Tania Maria. "Edição de entrevista: de linguagem falada à escrita". In: História Oral: um espaço plural. In: MONTENEGRO, Antônio Torres; FERNANDES, Tania Maria (Orgs.). História Oral: um espaço plural. Recife: Universitária, 2001.

HOBSBAWM, Eric. 68. Disponível em: http://members.tripod.com/ Picheli/Hobsbawm.htm. Acesso em: 25/03/18.

MECHI, Patrícia. "A Guerrilha do Araguaia e a repressão contra camponeses: reflexões sobre os fundamentos e as práticas repressivas do estado brasileiro em tempos de ditadura". História Revista, v. 20, n. 1, p. 48-70, 2015.

MONTENEGRO, Antônio Torres; FERNANDES, Tania Maria (Orgs.). História Oral: um espaço plural. Recife: Universitária, 2001.

O Livro Vermelho: citações do comandante Mao Tse-tung. São Paulo, Martin Claret, 2004.

O Décimo Congresso Nacional do Partido Comunista da China. Edições em línguas estrangeiras, Pequim, 1973. Impresso na República Popular da China.

PAES, Maria Helena Simões. A década de 60: Rebeldia, contestação e repressão política. $3^{\text {a }}$ ed. São Paulo: Ed. Ática, 1995.

RAPCHAN, Eliane Sebeika. "O uso da narrativa nas Ciências Sociais: algumas notas e reflexões acerca de suas possibilidades". In: MONTENEGRO, Antônio Torres; FERNANDES, Tania Maria (Orgs.). História Oral: um espaço plural. Recife: Universitária, 2001.

“Revolução Cultural na China mexeu com a estrutura política do país". Disponível em: $w w w$.educaterra.terra.com.br/revolucaocultural

SIJIE, Dai. Balzac e a Costureirinha Chinesa. Rio de Janeiro: Objetiva, 2001.

WITKE, Roxane. A Madame Mao. Rio de Janeiro: Nova Fronteira, 1977. 